\title{
Pengaruh Price Discount dan Bonus Pack terhadap Impulse Buying melalui Nilai Hedonik di Carrefour Surakarta
}

\author{
Sri Isfantin Puji Lestari \\ STIE Wijaya Mulya Surakarta \\ Korespondensi penulis: isfantin63@yahoo.com
}

Article Info:

Received 25 June 2018

Accepted 29 June 2018

Available online 30 June 2018 hedonic shopping value and impulse buying. This study also shows that the hedonic shopping value is an intervening variables that can mediate the effect of price discount and bonus pack variables on impulse buying.

Keywords: Bonus pack, Hedonic shopping value, Impulse buying, Price discount.

\section{LATAR BELAKANG}

Seiring semakin maju dan modernnya zaman menyebabkan munculnya berbagai usaha bisnis yang bertujuan untuk memuaskan pelanggan. Salah satu bisnis yang dikembangkan di wilayah perkotaan adalah usaha ritel. Hal ini menimbulkan persaingan yang ketat dari masing-masing bisnis ritel. Bisnis ritel akan memunculkan banyak retailer yang menawarkan banyak pilihan sesuai dengan kebutuhan untuk memuaskan pelanggan, baik dari segi kualitas produk, layanan, maupun harga produk. Dari persaingan yang muncul, hanya perusahaan unggul yang mampu bertahan dengan kualitas dan mampu memuaskan pelanggan sesuai dengan kebutuhan dan keinginan mereka.

Setiap perusahaan memiliki strategi masing-masing guna memasarkan produk untuk menarik ketertarikan pelanggan. Ketertarikan pelanggan akan produk yang diberikan membuat pelanggan merasa senang dan akhirnya akan loyal kepada produk, sehingga kepercayaan pelanggan terhadap perusahaan akan lebih mudah terbentuk. Hal ini memberikan kemudahan kepada perusahaan untuk menarik pelanggan selanjutnya. Pemasaran produk dari perusahaan dapat melalui berbagai cara antara lain brosur, pamflet, iklan di televisi, dan promosi tertentu pada penjualan produk.

Dilihat dari kegiatan pemasaran, pembelian terdiri atas dua macam, yaitu pembelian yang terencana dan pembelian yang tidak direncanakan sebelumnya. 
Pembelian yang terencana didasarkan pada kebutuhan pelanggan, sedangkan yang tidak terencana (impulse buying) merupakan perilaku pelanggan yang melakukan pembelian tanpa ada rencana sebelumnya. Menurut Mowen \& Minor (2002) pembelian yang tidak terencana (impulse buying) adalah tindakan membeli yang dilakukan tanpa memiliki masalah sebelumnya atau maksud/niat membeli yang terbentuk sebelum memasuki toko. Hal yang sama juga diungkapkan oleh Schiffman dan Kanuk (2000) yang menyatakan bahwa impulse buying merupakan keputusan yang emosional atau menurut desakan hati. Keputusan membeli yang tidak terencana sebelumnya dapat muncul karena pelanggan tertarik dan promosi yang diberikan dirasa cocok, seperti cash back, price discount, bonus pack, undian, hadiah, dan kupon.

Price discount dan bonus pack merupakan promosi penjualan yang banyak digunakan, baik penjualan online maupun offline (Chen, Marmorstein, Tsiro, \& Rao, 2012; Dawson \& Kim, 2009). Price discount adalah strategi promosi penjualan berbasis harga, ketika pelanggan ditawarkan produk yang sama dengan harga yang berkurang, sedangkan menurut Belch \& Belch (2009), bonus pack merupakan strategi penawaran dengan muatan ekstra dari sebuah produk lain dengan harga normal. Waani dan Tumbuan (2005) dalam penelitiannya menyatakan bahwa bonus pack merupakan salah satu variabel yang berpengaruh signifikan terhadap pembelian impulsif (impulse buying). Berdasarkan hasil penelitian dari Kurniawan dan Yohanes (2013), terdapat pengaruh yang positif dan signifikan promosi terhadap impulse buying di Matahari department store cabang supermall Surabaya. Salah satu indikator dari promosi tersebut adalah price discount atau diskon harga. Semakin tinggi tingkat promosi, maka akan semakin tinggi pula keputusan impulse buying (Putri, 2014). Pernyataan tersebut juga didukung oleh penelitian yang dilakukan oleh $\mathrm{Xu}$ et al. (2014) yang menyatakan bahwa diskon harga akan memicu niat membeli impulsif.

Park (2006) dalam penelitiannya menyebutkan bahwa impulse buying dipengaruhi oleh beberapa hal, salah satunya pengalaman yang bersifat hedonik. Hal yang sama diungkapkan oleh Silvera et al. (2008) yang mengungkapkan bahwa kesenangan didorong karena pencapaian tujuan yang bersifat hedonik. Hausman (2000) mengungkapkan bahwa nilai hedonik dapat dipuaskan dengan perasaan emosional yang timbul dari interaksi sosial yang diperoleh saat berbelanja. Tjiptono (2008) mengkategorikan diskon harga sebagai salah bentuk promosi penjualan. Parguel et al. (2007) juga memaparkan bahwa pengecer (retailer) menggunakan promosi penjualan dalam berbagai cara yang intensif untuk menarik perhatian pelanggan dan meningkatkan penjualan. Terkait dengan nilai hedonik, Arnold dan Reynolds (2003) mengungkapkan jika harga diskon merupakan salah satu faktor yang dapat memotivasi pelanggan untuk melakukan belanja hedonik. Artinya, pada kategori tersebut pelanggan melakukan aktivitas belanja untuk mendapatkan promosi penjualan (bonus pack), mencari potongan tunai (diskon), dan harga termurah.

Atas dasar latar belakang dan penelitian terdahulu, penelitian ini melakukan kajian secara komprehensif tentang pengaruh price discount dan bonus pack terhadap nilai hedonik dan impulse buying, pengaruh nilai hedonik terhadap impulse buying, dan nilai hedonik sebagai mediasi pengaruh price discount dan bonus pack terhadap impulse buying. Karena masih ada hasil kajian sebelumnya yang belum konsisten hasilnya, sehingga menimbulkan peluang yang menarik untuk dilakukan pengkajian ulang. Seperti penelitian Waani dan Tumbuan (2005) dalam penelitiannya menyatakan bahwa bonus pack dan in-store display berpengaruh signifikan terhadap pembelian impulsif 
(impulse buying), tetapi price discount terbukti tidak berpengaruh terhadap impulse buying.

\section{KAJIAN TEORITIS}

\section{A. Price Discount (Potongan Harga)}

1. Pengertian price discount (potongan harga)

Harga adalah jumlah uang yang dibutuhkan untuk mendapatkan sejumlah kombinasi dari produk dan pelayanannya (Swastha \& Irawan, 2008:241). Menurut Supranto dan Limakrisna (2011:12), harga adalah sejumlah uang yang harus dibayar untuk mendapatkan hak penggunaan produk. Definisi yang sama juga dipaparkan oleh Tjiptono dan Chandra (2008) bahwa harga adalah jumlah uang atau satuan moneter dan non-moneter yang mengandung kegunaan tertentu yang diperlukan untuk mendapatkan sebuah produk. Menurut Kotler yang dikutip (Molan, 2005:299), pengertian diskon adalah pengurangan langsung dari harga barang pada pembelian selama suatu periode waktu yang dinyatakan, sedangkan menurut Tjiptono (2007:166), diskon merupakan potongan harga yang diberikan oleh penjual kepada pembeli sebagai penghargaan atas aktivitas tertentu dari pembeli yang menyenangkan bagi penjual.

Menurut Machfoedz (2005:141), potongan harga (Price Discount) adalah potongan harga yang menarik, sehingga harga sesungguhnya lebih rendah dari harga umum, sedangkan menurut Sutisna (2001:303), potongan harga adalah pengurangan harga produk dari harga normal dalam periode tertentu. Berdasarkan pendapat yang telah diuraikan tersebut, peneliti dapat mendefinisikan bahwa harga diskon adalah penurunan harga di beberapa produk pada periode tertentu. Strategi harga diskon pada penjual merupakan strategi dengan memberikan potongan harga dari harga yang telah ditetapkan demi meningkatkan penjualan suatu produk barang atau jasa. Diskon dapat diberikan secara umum dalam bentuk diskon kuantitas, diskon pembayaran tunai (cash), dan trade discount (diskon penjualan). Perusahaan memodifikasi harga dasar suatu produk untuk memberi hadiah kepada pelanggan atas pembayaran awal, volume pembelian, dan pembelian di luar musim. Satyo (2013) menggambarkan price discount dengan tiga indicator, yaitu diskon double hemat, voucher diskon, dan diskon merk sebagai cara promosi yang tepat.

Menurut Abdullah dan Tantri (2015:189) penyesuaian harga yang disebut diskon dan potongan pembelian, di antaranya adalah:
a. Diskon/potongan kas
Diskon kas adalah pengurangan harga kepada konsumen yang membayar kewajiban mereka dengan tepat waktu.
b. Diskon/potongan jumlah
Diskon jumlah adalah pengurangan harga bagi pembeli dalam jumlah besar (tertentu).
c. Diskon/potongan fungsional 
Diskon fungsional (juga disebut diskon perdagangan) ditawarkan oleh produsen kepada anggota saluran perdagangan, jika mereka akan membentuk fungsi tertentu, seperti penjualan, pertokoan, dan penyimpanan. Produsen dapat menawarkan diskon fungsional yang berbeda kepada saluran perdagangan yang berbeda karena fungsi-fungsi mereka yang yang yang bermacam-macam, tetapi produsen harus menawarkan diskon fungsional yang sama kepada setiap saluran perdagangan.

d. Diskon/potongan musiman

Diskon musiman adalah pengurangan harga bagi pembeli yang membeli dagangan atau jasa di luar musimnya. Diskon musiman memungkinkan penjual untuk mempertahankan produksi yang tetap selama setahun.

e. Diskon/potongan pembelian

Potongan pembelian adalah jenis lain pengurangan dari harga dasar.

2. Tujuan price discount (potongan harga)

Menurut Alma (2012), potongan harga diberikan kepada konsumen disebabkan oleh beberapa hal, yaitu:

a. Konsumen membayar lebih cepat dari waktu yang telah ditentukan.

b. Pembelian dalam jumlah besar.

c. Adanya perbedaan timbangan.

d. Dari pihak produsen sendiri kemungkinan merupakan suatu program.

3. Jenis price discount (potongan harga)

Menurut Alma (2012), dua jenis potongan harga adalah:

a. Rabat: potongan yang diterima berupa pengurangan harga dari daftar harga yang resmi.

b. Potongan tunai: pengurangan harga kepada pembeli yang membayar tagihan mereka lebih awal. Metode potongan ini diberikan berdasarkan pertimbangan-pertimbangan, jumlah pembelian, prosedur pembayaran dan juga tergantung pada taktik promosi produsen atau penjual. Meskipun potongan harga merupakan salah satu strategi dalam penetapan harga untuk menarik perhatian konsumen, tetapi potongan harga secara langsung memberikan dampak positif terhadap konsumen yang berpendapatan rendah.

\section{B. Bonus Pack}

\section{Pengertian Bonus Pack}

Menurut Belch dan Belch (2009), bonus pack menawarkan konsumen sebuah muatan ekstra dari sebuah produk dengan harga normal. Kotler (2003) mendefinisikan bonus pack adalah "reduce price pack is a single package sold a reduce price," yaitu bonus dalam kemasan yang dijual pada pengurangan harga. Promosi bonus pack termasuk dalam salah satu komponen di dalam sales promotion yang digunakan untuk meningkatkan pembelian impulse yang dilakukan oleh konsumen. Jadi, bonus pack merupakan promosi penjualan yang dilakukan perusahaan untuk menawarkan produk tambahan secara gratis 
dengan harga normal, bahkan harga yang telah diturunkan sebelumnya untuk mendorong konsumen melakukan pembelian.

2. Manfaat Bonus Pack

Belch dan Belch (2009) menyebutkan manfaat dari penggunaan strategi bonus pack ini adalah:

a. Memberikan pemasar cara langsung untuk menyediakan nilai ekstra.

b. Merupakan strategi bertahan yang efektif terhadap kemunculan promosi produk baru dari pesaing.

c. Menghasilkan pesanan penjualan yang lebih besar.

Belch dan Belch (2009) juga menyatakan bahwa bonus pack menawarkan konsumen muatan ekstra dari sebuah produk dengan harga biasa yang tersusun dari tiga indicator, yaitu memberikan penawaran dengan manfaat ekstra, strategi bertahan terhadap promosi produk baru, dan menghasilkan pesanan penjualan yang lebih besar.

\section{Nilai Hedonik}

Zhang et al. (2011) menemukan bahwa nilai hedonik merupakan realisasi dari rangsangan lingkungan berbelanja. Nilai hedonik konsumsi merupakan pengalaman konsumsi yang berhubungan dengan perasaan, fantasi, kesenangan, dan panca indera, yaitu pengalaman tersebut mempengaruhi emosi seseorang (Hirsman \& Holbrook, 1986). Hausman (2000) menyatakan bahwa nilai hedonik dapat dipuaskan dengan perasaan emosional yang timbul dari interaksi sosial yang didapatkan saat berbelanja. Hausman (2000) mengungkapkan bahwa nilai hedonik dapat dipuaskan dengan perasaan emosional yang timbul dari interaksi sosial yang diperoleh saat berbelanja. Tjiptono (2008) mengkategorikan diskon harga sebagai salah bentuk promosi penjualan. Parguel et al. (2007) juga memaparkan bahwa pengecer menggunakan promosi penjualan dalam berbagai cara yang intensif untuk menarik perhatian pelanggan dan meningkatkan penjualan.

Terkait dengan nilai hedonik, Arnold dan Reynolds (2003) mengungkapkan jika harga diskon merupakan salah satu faktor yang dapat memotivasi pelanggan untuk melakukan belanja hedonik. Artinya, pada kategori tersebut pelanggan melakukan aktivitas belanja untuk mendapatkan promosi penjualan (bonus pack), mencari potongan tunai (diskon), dan harga termurah. Hausman (2000) mengungkapkan nilai hedonik konsumsi diukur dengan enam indikator, yaitu mencari kesenangan baru, memuaskan rasa ingin tahu, pengalaman baru, bertemu dengan orang lain, mencari hiburan, dan melupakan persoalan.

\section{Impulse Buying}

Impulse buying (pembelian impulsif) adalah suatu pembelian yang tidak terencana, yang dicirikan dengan keputusan pembelian yang relatif cepat, dan keinginan untuk segera memiliki barang tersebut. Tipe pembelian ini juga diikuti dengan adanya dorongan emosional. Dorongan emosional tersebut terkait dengan adanya perasaan yang intens dan ditunjukkan dengan melakukan pembelian karena adanya dorongan untuk membeli suatu produk dengan segera, merasakan kepuasan, dan mengabaikan konsekuensi negatif (Rook, 1987). Menurut Beatty dan Ferrell 
(1998), pembelian impulsif merupakan suatu pembelian yang tiba-tiba dan langsung tanpa ada niat belanja sebelumnya, baik untuk membeli suatu produk tertentu atau untuk memenuhi suatu kewajiban tertentu. Bayley dan Nancarrow (1998) dalam Muruganantham dan Bhakat (2013) mendefinisikan pembelian impulsif sebagai suatu pembelian yang tiba-tiba dan mendesak, ketika kecepatan dalam mengambil keputusan menghalangi berbagai pertimbangan bijaksana dan pencarian pilihan alternatif lain. Keputusan membeli dalam pembelian impulsif sangatlah cepat, karena waktu yang dibutuhkan dari melihat produk sampai membeli adalah pendek.

Hausman (2000) mengungkapkan bahwa pembelian impulsif diukur dengan indikator: (1) Spontan, konsumen cenderung melakukan keputusan secara spontan; (2) Melihat langsung membeli, konsumen cenderung melakukan keputusan dengan segera; (3) Bertindak tanpa berpikir, konsumen cenderung melakukan keputusan tanpa berpikir; dan (4) Beli sekarang, konsumen cenderung melakukan keputusan sesukanya.

\section{METODE PENELITIAN}

Rancangan penelitian atau disain riset dalam penelitian ini dimulai dari perumusan masalah, memformulasikan tujuan penelitian, identifikasi variabel, menentukan metode pengumpulan data dengan penyebaran kuesioner ke sejumlah responden terpilih (sampel), dan teknik pengumpulan data yang digunakan, kemudian membuat dan menentukan model analisisnya, serta teknik estimasi yang digunakan. Langkah selanjutnya adalah melakukan interpretasi hasil penelitian untuk membuat kesimpulan penelitian.

Berdasarkan uraian di atas maka penelitian yang penulis lakukan menggunakan disain kausal, karena bertujuan untuk mengukur hubungan kausalitas antara beberapa variable, yaitu variabel Price Discount, dan Bonus Pack terhadap Nilai Hedonik dan Impulse Buying pada pelanggan Carrefour di Surakarta. Penelitian ini menggunakan survei eksplanasi (explanatory survey), karena peneliti akan menjelaskan hubungan kausal antara variabel-variabel melalui pengujian hipotesis. Metode penelitian yang digunakan adalah survei, yaitu penelitian yang mengambil sampel dari populasi dengan menggunakan kuesioner dari jumlah populasi yang banyak (Singarimbun, 1993:47). Survei bukan semata-mata untuk membuat diskripsi tentang suatu keadaan melainkan juga untuk menjelaskan hubungan pengaruh antarberbagai variabel yang diteliti (Allen, 1997:34).

Untuk memprediksi besarnya variasi, bentuk hubungan, dan menentukan arah dan besarnya pengaruh antara variabel bebas dengan variabel terikat, penelitian ini menggunakan teknik analisis SEM (Structural Equation Modelling) yang dioperasikan melalui program AMOS (Analysis of Moment Structure) for Windows version 23. Untuk memperoleh gambaran yang lengkap tentang pokok bahasan tersebut, penelitian ini dimulai dari data diskriptif yang berhubungan dengan variabel-variabel penelitian, kemudian dilakukan analisis inferensial untuk membuktikan hipotesis penelitian. 
A. Populasi

Populasi penelitian ini mencakup pelanggan beberapa Carrefour di Surakarta. Teknik pengambilan sampel yang digunakan dalam penelitian ini menggunakan simple random sampling.

B. Sampel dan Besarnya Sampel

Ukuran sampel sesuai dengan kebutuhan SEM menurut Ferdinand (2002) adalah sebanyak 100-200 sampel. Oleh karena itu, penelitian ini menggunakan 200 pelanggan Carrefour di Surakarta sebagai sampel.

C. Teknik Analisis Data

Untuk menjawab permasalahan penelitian, teknik analisis yang digunakan dalam penelitian ini adalah:

\section{Analisis Diskriptif}

Analisis diskriptif yang digunakan adalah tabulasi data dengan distribusi frekuensi terhadap variabel-variabel penelitian dari kuesioner yang telah diisi oleh responden, sehingga menghasilkan output untuk pengambilan keputusan. Sifat-sifat data dapat diketahui dengan cara menghitung mean (rerata). Analisis ini dilakukan untuk mengetahui bagaimana distribusi jawaban responden terhadap kuesioner yang meliputi variabel beserta masing masing indikator yang menjadi pilihan responden .

2. Analisis SEM (Structural Equation Modeling)

Model yang digunakan dalam penelitian ini adalah model kausalitas atau hubungan dan pengaruh (Gambar 1). Untuk menguji hipotesis yang diajukan dalam penelitian ini, teknik analisis yang digunakan adalah SEM yang dioperasikan dengan menggunakan paket program AMOS versi 23 dan SPSS versi 23.0.

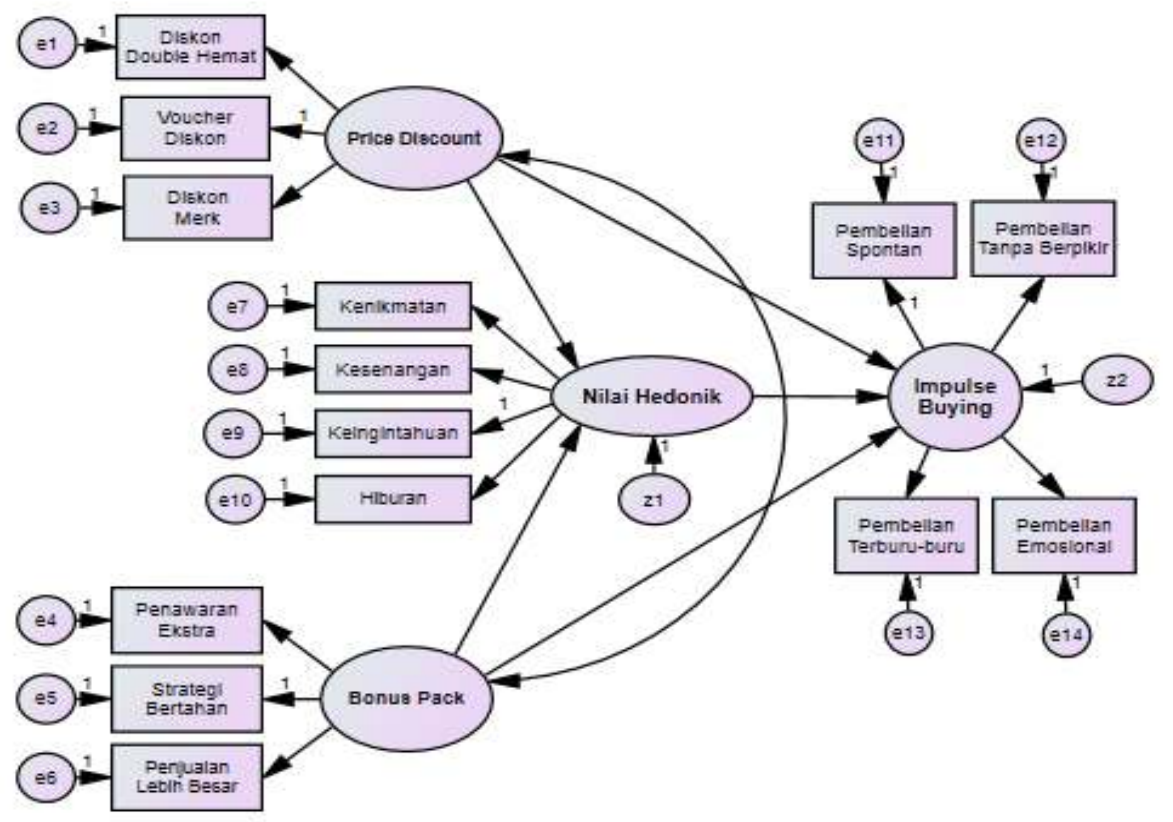

Gambar 1. Model Penelitian 


\section{HASIL DAN PEMBAHASAN}

Penelitian ini dilakukan pada Januari 2018 dengan menyebarkan kuesioner kepada sejumlah pelanggan Carrefour di Surakarta sebagai responden. Hasil dari tanggapan responden terhadap pernyataan yang ada di kuesioner selanjutnya dianalisis menggunakan analisis SEM. Analisis SEM memiliki beberapa tahapan. Sebelum dilakukan pengujian model, peneliti melakukan beberapa pengujian, seperti uji validitas dan uji reliabilitas, uji asumsi SEM, dan analisis hasil uji SEM. Berdasarkan hasil pengujian diketahui bahwa semua koefisien korelasi memiliki nilai lebih besar dari $\mathrm{r}$ tabel $(0,361)$, sehingga dapat disimpulkan bahwa semua butir pernyataan pada masingmasing variabel dapat dikatakan valid dan dapat dipergunakan untuk pengujian selanjutnya. Uji reliabilitas digunakan untuk menguji sejauh mana alat ukur relatif konsisten apabila pengukuran diulang dua kali atau lebih. Hasil uji reliabilitas menunjukkan bahwa semua nilai Cronbach's Alpha lebih besar dari 0,6. Hasil tersebut menunjukkan bahwa setiap butir pernyataan yang diajukan untuk masing-masing variabel terbukti andal digunakan pada analisis lebih lanjut.

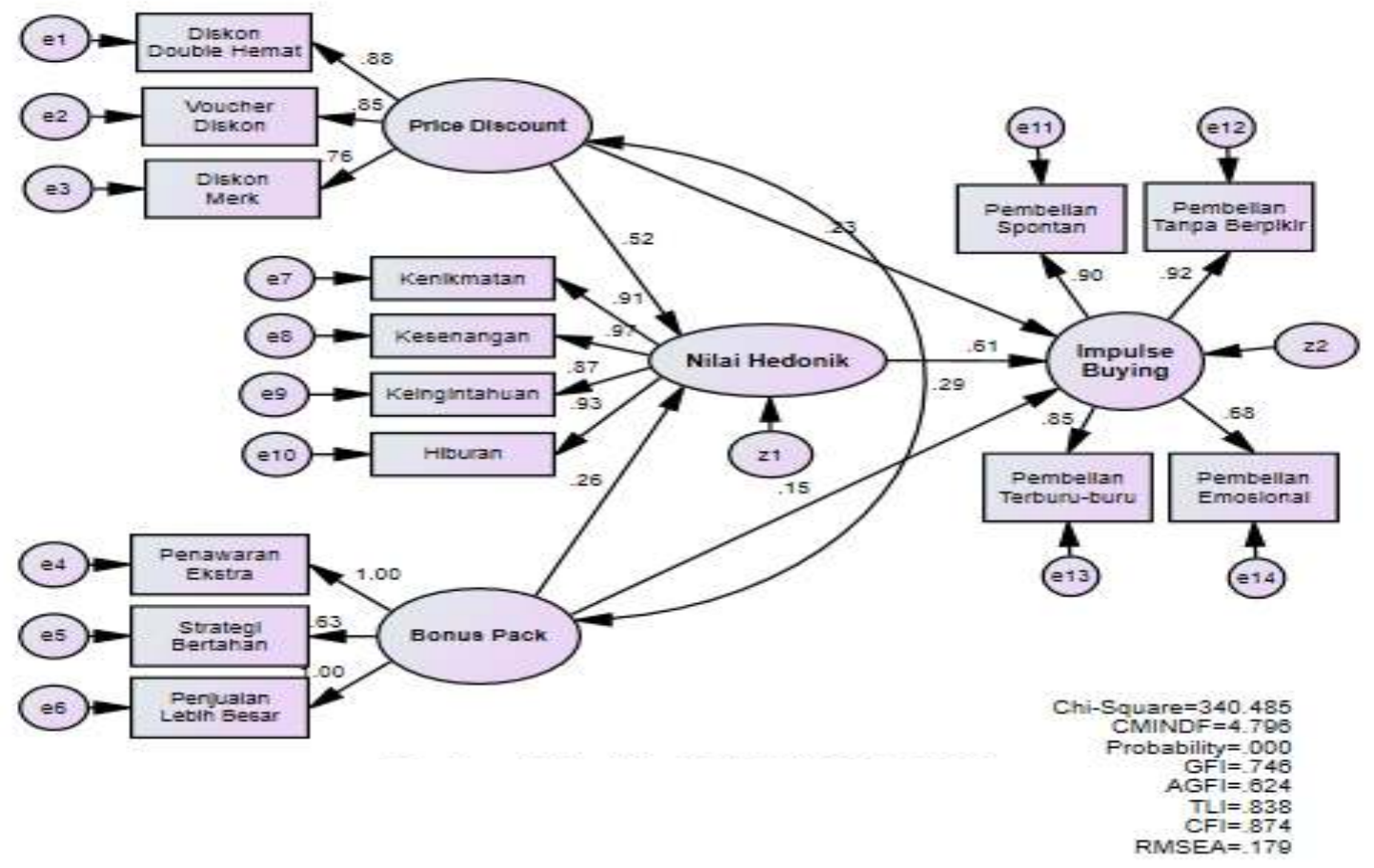

Gambar 2. Hasil Analisis SEM

Hasil evaluasi kriteria Goodness of Fit Indices pada Gambar 2 menunjukkan bahwa evaluasi model secara keseluruhan sudah memenuhi dilihat dari nilai Chi-Square yang kecil, sehingga model dapat diterima. Dalam menjelaskan pengaruh variabel eksogen terhadap variabel endogen digunakan persamaan struktural. Hasil koefisien dapat dilihat pada Tabel 1 sebagai berikut: 
Tabel 1. Hasil Pengujian Hipotesis

\begin{tabular}{ccccc}
\hline Variabel Endogen & Variabel Eksogen & B & CR & P \\
\hline Nilai Hedonik $\left(\mathrm{Y}_{1}\right)$ & Price Discount $\left(\mathrm{X}_{1}\right)$ & 0,865 & 5,671 & $* * *$ \\
& Bonus Pack $\left(\mathrm{X}_{2}\right)$ & 0,520 & 3,057 & 0,002 \\
\hline Impulse Buying $\left(\mathrm{Y}_{2}\right)$ & Price Discount $\left(\mathrm{X}_{1}\right)$ & 0,324 & 2,929 & 0,003 \\
& Bonus Pack $\left(\mathrm{X}_{2}\right)$ & 0,263 & 2,398 & 0,016 \\
& Nilai Hedonik $\left(\mathrm{Y}_{1}\right)$ & 0,513 & 6,992 & $* * *$ \\
\hline
\end{tabular}

Hasil pengujian hipotesis menunjukkan bahwa nilai probabilitas yang dihasilkan semua variabel memiliki tingkat kesalahan $\leq 5 \%$ dan nilai $\mathrm{CR}$ lebih dari dua. Hal ini menunjukkan bahwa price discount dan bonus pack berpengaruh signifikan terhadap nilai hedonik dan impulse buying, nilai hedonik berpengaruh signifikan terhadap impulse buying, serta price discount dan bonus pack berpengaruh terhadap impulse buying melalui nilai hedonik pelanggan Carrefour di Surakarta.

Berdasarkan hasil penelitian tersebut, price discount dijelaskan oleh diskon dobel hemat, voucher discount, dan diskon merk. Dari ketiga indikator tersebut, diskon dobel hemat dipersepsikan paling kuat dalam membentuk diskon harga bagi pelanggan Carrefour di Surakarta. Hal ini sejalan dengan hasil penelitian Satyo (2013) yang menggambarkan price discount dengan tiga indicator, yaitu diskon dobel hemat, voucher discount, dan diskon merk sebagai cara promosi yang tepat.

Berdasarkan hasil penelitian ini, bonus pack dibentuk melalui indikator penawaran ekstra, strategi bertahan, dan penjualan lebih besar. Indikator penawaran ekstra menjadi indikator terkuat yang dipersepsikan responden dalam membentuk variabel bonus pack. Hal ini sejalan dengan penelitian Belch dan Belch (2009) yang menyatakan bahwa bonus pack menawarkan kepada konsumen muatan ekstra dari sebuah produk dengan harga biasa yang tersusun dari tiga indicator, yaitu memberikan penawaran dengan manfaat ekstra, strategi bertahan terhadap promosi produk baru, dan menghasilkan pesanan penjualan yang lebih besar.

Berdasarkan hasil analisis yang telah dilakukan, variabel nilai hedonik dibentuk atas dasar indikator kenikmatan, kesenangan, keingintahuan, dan hiburan. Indikator kesenangan menjadi indikator yang dipersepsikan paling kuat oleh responden dalam membentuk variabel nilai hedonik. Hal ini sejalan dengan penelitian Hausman (2000) yang menyatakan bahwa nilai hedonik konsumsi diukur dengan indikator, yaitu mencari kesenangan baru, memuaskan rasa ingin tahu, pengalaman baru, bertemu dengan orang lain, mencari hiburan, dan melupakan persoalan.

Berdasarkan hasil analisis dalam penelitian ini, variabel impulse buying dibentuk dari indikator pembelian spontan, pembelian tanpa berpikir, pembelian terburu-buru, dan pembelian dipengaruhi oleh emosional. Hal ini sejalan dengan penelitian Hausman (2000) yang mengungkapkan bahwa pembelian impulsif diukur dengan indikator: (1) Spontan, konsumen cenderung melakukan keputusan secara spontan, (2) Melihat langsung membeli, konsumen cenderung melakukan keputusan dengan segera, (3) 
Bertindak tanpa berfikir, konsumen cenderung melakukan keputusan tanpa berfikir, dan (4) Beli sekarang, konsumen cenderung melakukan keputusan sesukanya. Indikator pembelian tanpa berpikir menjadi indikator paling kuat dalam membentuk variabel impulse buying.

Berdasarkan hasil uji hipotesis membuktikan bahwa price discount dan bonus pack berpengaruh terhadap nilai hedonik. Hal ini dapat dikatakan bahwa semakin menarik diskon harga yang diberikan dan semakin banyak bonus pack yang diberikan Carrefour terhadap pelanggan, maka akan semakin tinggi nilai hedonik yang dirasakan pelanggan. Artinya, terciptanya nilai hedonik pada pelanggan Carrefour di Surakarta disebabkan diskon harga yang diberikan melalui program diskon double hemat. Banyak produk Carrefour yang ditawarkan dengan diskon harga yang menarik, seperti produk sembako, kebutuhan sehari-hari, maupun elektronik. Salah satu contoh diskon double hemat adalah contoh produk susu, yaitu pembelian tiga kardus susu mendapatkan diskon $25 \%$ dengan setiap kardusnya sudah ditawarkan harga diskon. Tidak hanya itu, apabila pelanggan menggunakan kartu kredit, maka akan mendapatkan potongan harga sebesar 5-10\%. Hal ini menjadikan pelanggan merasa senang dan tanpa berpikir lebih jauh, pelanggan melakukan pembelian karena diskon yang ditawarkan sangatlah menarik. Hasil ini sejalan dengan penelitian yang dilakukan Putri (2014) dan Xu et al. (2014) yang menyatakan bahwa semakin tinggi tingkat promosi, maka akan semakin tinggi pula keputusan impulse buying.

Tidak hanya price discount yang dapat meningkatkan perasaan hedonik kepada pelanggan Carrefour di Surakarta, tetapi bonus pack yang diberikan oleh pihak Carrefour juga dapat meningkatkan nilai hedonik yang dirasakan pelanggan. Penawaran ekstra menjadi hal yang sangat mempengaruhi nilai hedonik yang dirasakan oleh pelanggan Carrefour, karena penawaran yang diberikan selalu bervariasi. Hal tersebut membuat pelanggan menjadi senang, karena pelanggan merasa mendapatkan produk lebih yang akan didapatkan dengan harga yang biasa. Salah satu contoh bonus pack yang diberikan oleh Carrefour adalah produk susu, yaitu pembelian satu dus mendapatkan bonus tempat minum yang cukup bagus. Bonus pack yang ditawarkan oleh Carrefour dapat menarik pelanggan, karena bonus yang diberikan masih berhubungan dengan produk utama yang ditawarkan, sehingga banyak pelanggan yang tadinya tidak terpikir untuk membeli, kemudian ia melakukan pembelian produk tersebut (impulse buying). Hasil ini sejalan dengan penelitian yang dilakukan Waani dan Tumbuan (2005) bahwa bonus pack merupakan salah satu variabel yang berpengaruh signifikan terhadap pembelian impulsif (impulse buying).

Hasil penelitian ini menunjukkan bahwa price discount dan bonus pack mempengaruhi impulse buying melalui nilai hedonik. Nilai hedonik mampu memediasi pengaruh antara price discount dan bonus pack terhadap impulse buying pelanggan Carrefour di Surakarta. Nilai hedonik yang dirasakan oleh pelanggan Carrefour akan muncul di saat pelanggan merasakan kesenangan saat berbelanja ketika melihat diskon harga (price discount) melalui harga paket hemat, dan bonus pack yang menarik sesuai dengan produk utama yang ditawarkan oleh Carrefour, sehingga tanpa berpikir lagi, pelanggan akan membeli produk tersebut (impulse buying). Hausman (2000) mengungkapkan bahwa nilai hedonik dapat dipuaskan dengan perasaan emosional yang timbul dari interaksi sosial yang diperoleh saat berbelanja. Hal itu dipertegas dengan penelitian Silvera et al. (2008) yang menyatakan bahwa pencapaian tujuan yang bersifat hedonik didorong oleh kesenangan. Kesenangan yang muncul pada pelanggan Carrefour dapat mendorong seseorang melakukan pembelian impulsif (impulse buying). Hal 
senada diungkapkan Park (2006) dalam penelitiannya yang menyebutkan bahwa impulse buying dipengaruhi oleh beberapa hal yang salah satunya adalah pengalaman yang bersifat hedonik.

\section{SIMPULAN}

Berdasarkan hasil analisis dan pembahasan di atas, maka dapat disimpulkan bahwa promosi yang dilakukan oleh Carrefour di Surakarta melalui pemberian price discount dan bonus pack dapat mempengaruhi perasaan nilai hedonik pelanggan, yaitu ia akan merasa senang dan pada akhirnya melakukan pembelian tanpa berpikir terlebih dahulu. Keterbatasan dalam penelitian ini adalah nilai loading factor dari indikator strategi bertahan yang kecil dalam membentuk variabel bonus pack. Oleh karena itu, penelitian selanjutnya disarankan untuk mengkaji ulang indikator strategi bertahan atau menggantinya dengan indikator yang lain.

\section{DAFTAR REFERENSI}

Allen, N. J. \& Meyer, J. P. (1990). The Measurement and Antecedent of Affective, Continuance and Normative Commitment to the Organization. Journal of Occupational Psychology, 91, 1-18.

Alma, B. (2012). Manajemen Pemasaran dan Pemasaran Jasa. Edisi Keenam. Bandung: Alfabeta.

Arnold, M. J. \& Reynold, K. E. (2003). Hedonic Shopping Motivation. Journal of Retailing, 79(2), 77-95.

Bayley, G. \& Nancarrow, C. (1998). Impulse purchasing: a qualitative exploration of the phenomenon. Qualitative Market Research: An International Journal, 1(2), 99-114.

Beatty, S. E. \& Ferrell, M. E. (1998). Impulse Buying: Modeling Its Precursors. Journal of Retailing, 74(2), 169-191.

Belch, G. E. \& Belch, M. A. (2009). Advertising and Promotion: An Integrated Marketing Communication Perspective. $8^{\text {th }}$ Edition. New York: Pearson Education.

Dawson, S. \& Kim, M. (2009). External and Internal trigger cues of impulse buying online. Direct Marketing: An International Journal, 3(1), 20-34.

Ferdinand, A. (2002). Structural Equation Modeling Dalam Penelitian Manajemen. Edisi 2. Semarang: NP Undip.

Hausman, A. (2000). A Multi Method Investigation of Consumer Motivation in Impulse Buying Behavior. Journal of Consumer Marketing, 17(5), 403-419.

Hirschman, E. C. \& Holbrook, M. B. (1982). Hedonic consumption: emerging concept, methods and proportions. Journal of Marketing, 46, 92-101.

Mowen, J. C. \& Minor, M. (2002) Perilaku Konsumen. Edisi Kelima. Jakarta: PT. Erlangga.

Park, E. J., Kim, E. Y. \& Judith, C.F. (2006). A Structural Model of Fashion-Oriented Impulse Buying Behavior. Journal of Fashion Marketing Management, 10(4), 433-446. 
Putri, Y. T. A. \& Edward, M. (2014). Pengaruh Bonus Pack dan Price Discount terhadap Impulse Buying pada Konsumen Giant Hypermarket Diponegoro Surabaya. Universitas Negeri Surabaya. Retrieved from http://http://jurnalmahasiswa. unesa.ac.id/index.php/jptn/article/view/12039.

Rook, D. W \& Fisher, R. J. (1995). Normative influences on impulse buying behavior. Journal of Consumer Research.

Schiffman, L. G. \& Kanuk, L.L. (2000). Consumer Behavior. $7^{\text {th }}$ edition. Prentice-Hall International, Inc.

Silvera, D. H., Lavack, A. M., \& Kropp, F. (2008). Impulse buying: the role of affect, social influence, and subjective wellbeing. Journal of Consumer Marketing, 25(1), 23-33.

Singarimbun, M. \& Sofian, E. (1993). Metode Penelitian Survai. Jakarta: LP3ES.

Tjiptono, F., Chandra, G. \& Andriana, D. (2008). Pemasaran Strategik. Yogyakarta: Andi Offset.

Tjiptono, F. (2008). Strategi Pemasaran. Edisi Ketiga. Yogyakarta: Andi Offset.

Zhang, Y., Sirion, C., \& Combs, H. (2011). The Influence of the mall environment on shopper's value and consumen behavior in China. ASBBS Annual Conference, 18(1), 214-224. 